\title{
Keratinocyte Growth Factor and Hepatocyte Growth Factor/ Scatter Factor Are Heparin-binding Growth Factors for Alveolar Type II Cells in Fibroblast-conditioned Medium
}

\author{
Ralph J. Panos, ${ }^{\star}$ Jeffrey S. Rubin, ${ }^{\ddagger}$ Stuart A. Aaronson, ${ }^{*}$ and Robert J. Mason ${ }^{\star}$ \\ ${ }^{*}$ Pulmonary Division, Department of Medicine, Northwestern University Medical School, Chicago, Illinois 60611; ${ }^{\ddagger}$ Laboratory of Cell \\ and Molecular Biology, National Cancer Institute, Bethesda, Maryland 20892; and ${ }^{\S}$ Pulmonary Division, National Jewish Center for \\ Immunology and Respiratory Medicine, University of Colorado Health Sciences Center, Denver, Colorado 80206
}

\begin{abstract}
Epithelial-mesenchymal interactions mediate aspects of normal lung growth and development and are important in the restoration of normal alveolar architecture after lung injury. To determine if fibroblasts are a source of soluble growth factors for alveolar type II cells, we investigated the effect of fibroblast-conditioned medium (CM) on alveolar type II cell DNA synthesis. Serum-free CM from confluent adult human lung fibroblasts was concentrated fivefold by lyophilization. Type II cells were isolated from adult rats by elastase dissociation and incubated with $\left[{ }^{3} \mathrm{H}\right]$ thymidine and varying dilutions of concentrated CM and serum from day 1 to 3 of culture. Stimulation of type II cell DNA synthesis by fibroblast-CM was maximal after $48 \mathrm{~h}$ of conditioning and required the presence of serum. The activity of the $\mathrm{CM}$ was eliminated by boiling and by treatment with trypsin, pepsin, or dithiothreitol and was additive with saturating concentrations of acidic fibroblast growth factor, epidermal growth factor, and insulin. The growth factor activity bound to heparin-Sepharose and was eluted with 0.6 and $1.0 \mathrm{M} \mathrm{NaCl}$. Neutralizing antibody studies demonstrated that the primary mitogens isolated in the 0.6 and $1.0 \mathrm{M} \mathrm{NaCl}$ fractions were keratinocyte growth factor (KGF, fibroblast growth factor 7) and hepatocyte growth factor/scatter factor (HGF/SF), respectively. HGF /SF was demonstrated in the crude $\mathrm{CM}$ and $\mathrm{KGF}$ was detected in the $0.6 \mathrm{M} \mathrm{NaCl}$ eluent by immunoblotting. Northern blot analysis confirmed that the lung fibroblasts expressed both KGF and HGF/SF transcripts. Human recombinant KGF and HGF/SF induced a concentration- and serum-dependent increase in rat alveolar type II cell DNA synthesis. We conclude that adult human lung fibroblasts produce at least two soluble heparin-binding growth factors, KGF and HGF/SF, which promote DNA synthesis and proliferation of rat alveolar type II cells in primary culture. KGF and HGF /SF may be important stimuli for alveolar type II cell proliferation during lung growth and after lung injury. ( $J$. Clin. Invest. 1993. 92:969-977.) Key words: alveolar type II cell - keratinocyte growth factor • hepatocyte growth factor • scatter factor
\end{abstract}

Address correspondence to Ralph J. Panos, M. D., Pulmonary Division, Department of Medicine, Northwestern University Medical School, Wesley Pavilion, Room 456, 250 East Superior Street, Chicago, IL 60611-2950. 1993.

Received for publication 16 July 1992 and in revised form 17 March

The Journal of Clinical Investigation, Inc.

Volume 92, August 1993, 969-977

\section{Introduction}

In most forms of diffuse lung injury, alveolar type I cells are destroyed and the alveolar epithelial lining is disrupted. Repair occurs when alveolar type II cells proliferate and differentiate into type I cells, restoring the integrity of the alveolar epithelium (1-3). If type II cell proliferation and differentiation are impaired, mesenchymal cells may migrate into the alveolar space or alveolar collapse may occur. Fibrosis ensues and alveolar gas exchange function is diminished $(4,5)$. Very little is known about the mechanisms that regulate the processes of cellular proliferation, differentiation, and repair in the alveolar epithelium after lung injury.

Leslie et al. (6-8) have demonstrated that factors such as insulin, cholera toxin, EGF, acidic fibroblast growth factor (aFGF), ${ }^{1}$ and medium conditioned by alveolar macrophages stimulate DNA synthesis in alveolar type II cells in primary culture. Brandes and Finkelstein (9) have also shown that stimulated macrophages secrete a factor(s) that induces proliferation of rabbit alveolar type II cells in vitro. In addition, Leslie et al. (10) described a factor(s) in bronchoalveolar lavage fluid (BALF) from normal rats that stimulates DNA synthesis in alveolar type II cells. No defined growth factor(s) has been identified in these conditioned media or in BALF, and the role of macrophages and BALF in alveolar type II cell proliferation after lung injury or during lung growth is not known. In a previous study, we did not find an increase in the normal BALF stimulatory activity after silica-induced lung injury, a condition characterized by proliferation of type II cells (11).

In addition to inflammatory cell-derived factors, epithelial-mesenchymal interactions are believed to mediate aspects of normal lung growth and development and may be important in alveolar epithelial repair (12-15). Everett et al. (16) have demonstrated that lung fibroblasts from hyperoxiatreated hamsters produce growth factor activity that stimulates DNA synthesis and cell division in rat alveolar type II cells in primary culture. Fetal lung fibroblast CM contains mitogenic activity for fetal alveolar type II cells (17). Although these fibroblast-derived growth factor activities for alveolar epithelial cells have been partially characterized, specific growth factor(s) have not heretofore been identified. In this report we demonstrate that adult human lung fibroblasts produce two recently described heparin-binding growth factors, keratinocyte growth

1. Abbreviations used in this paper: aFGF, acidic fibroblast growth factor; BALF, bronchoalveolar lavage fluid; CM, conditioned medium; HGF/SF, hepatocyte growth factor/scatter factor; KGF, keratinocyte growth factor; $r$, recombinant. 
factor (KGF) and hepatocyte growth factor/scatter factor (HGF/SF), that stimulate DNA synthesis and proliferation of rat alveolar type II cells in primary culture.

\section{Methods}

Isolation of alveolar type II cells and preparation of human lung fibroblast CM. Alveolar type II cells were isolated from specific pathogenfree Sprague-Dawley rats weighing 150-250 g (Bantin and Kingman, Inc., Fremont, CA) by elastase dissociation and purification on discontinuous metrizamide density gradients as described previously (18). Cell viability was determined by erythrocin B exclusion and the purity of alveolar type II cells was assessed by modified Papanicolaou staining (19). On the day of isolation, alveolar type II cell purity was $>75 \%$ and was $>90 \%$ on day 1 at the start of the thymidine incorporation assay. Cell viability was $>90 \%$ immediately after isolation. Adult human lung fibroblasts ( no. AG02262) were obtained from the National Institute of Aging, Cell and Culture Repository, Coriell Institute for Medical Research (Camden, NJ). The cells were obtained at population doubling 4. The human lung fibroblasts were cultured in DME (GIBCO-Bethesda Research Laboratories, Gaithersburg, MD) containing 10\% FCS (Sigma Chemical Co., St. Louis, MO), $2 \mathrm{mM}$ glutamine, $10 \mu \mathrm{g} / \mathrm{ml}$ gentamicin, $2.5 \mu \mathrm{g} / \mathrm{ml}$ amphotericin $\mathrm{B}, 100 \mathrm{U} / \mathrm{ml}$ penicillin $\mathrm{G}$, and $100 \mu \mathrm{g} / \mathrm{ml}$ streptomycin. The medium was changed every 2-3 d until the fibroblasts reached a dense confluency. The cells were then washed with DME and the medium was changed to DME without serum. The fibroblasts were maintained at $37^{\circ} \mathrm{C}$ in a humidified incubator containing $90 \%$ air $/ 10 \% \mathrm{CO}_{2}$. The lung fibroblast culture supernatant-CM was filtered, lyophilized, and stored at $-20^{\circ} \mathrm{C}$. Before use, the lyophilized CM was reconstituted in one-fifth the original volume with distilled water and then dialyzed against DME in dialysis tubing with a molecular weight cutoff of 3,500 (Spectra/Por; Spectrum Medical Industries, Inc., Los Angeles, CA). Henceforth this fivefold concentrated $\mathrm{CM}$ will be referred to as concentrated $\mathrm{CM}$.

Cell culture, DNA synthesis, and cell proliferation assays. Isolated alveolar type II cells were suspended in DME containing 10\% FCS and plated onto 48-well plates (Costar Corp., Cambridge, MA) at $10^{5}$ cells per well and maintained at $37^{\circ} \mathrm{C}$ in a humidified incubator containing $90 \%$ air $/ 10 \% \mathrm{CO}_{2}$. [ $\left.{ }^{3} \mathrm{H}\right]$ Thymidine incorporation was assayed as described previously (11). Briefly, $24 \mathrm{~h}$ after plating, the nonadherent alveolar type II cells were removed with the medium, and $0.5 \mathrm{ml}$ of concentrated $\mathrm{CM}, 0.5 \mu \mathrm{Ci}$ [ ${ }^{3} \mathrm{H}$ ] thymidine (adjusted to a specific activity of $1.12 \mu \mathrm{Ci} / \mathrm{nmol}$ ), and FCS were added to each well along with fresh media to bring the final volume to $1.0 \mathrm{ml}$ and the cells were incubated for $48 \mathrm{~h}$. Each condition was tested in duplicate or triplicate wells. To determine $\left[{ }^{3} \mathrm{H}\right]$ thymidine incorporation, the DNA was precipitated with cold $10 \%$ TCA, solubilized with $1.0 \mathrm{M}$ sodium hydroxide, and aliquots were counted by liquid-scintillation spectrometry. To determine cell number, cells were plated in DME containing $10 \%$ FCS at $5 \times 10^{5}$ cells per $35-\mathrm{mm}$ dish. On day 1 , the nonadherent cells were removed with medium, and the growth factor(s) and 10\% FCS in DME were added. After a 2-d incubation, the cells were washed with unsupplemented DME and harvested with $0.05 \%$ trypsin in $0.053 \mathrm{mM}$ EDTA (GIBCO-Bethesda Research Laboratories). Trypsin was inactivated by an equal volume of DME containing $10 \%$ FCS, and the cells were counted in a hemocytometer. Autoradiography and determination of alveolar type II cell nuclear labeling index were performed as described previously (11). The time-dependent accumulation of stimulatory activity for alveolar type II cells in human lung fibroblast-CM was determined by harvesting the fibroblast supernatant-CM after 6 , $12,24,48,72$, and $96 \mathrm{~h}$. These media were lyophilized, concentrated fivefold, and then tested in the alveolar type II cell $\left[{ }^{3} \mathrm{H}\right]$ thymidine incorporation assay at a concentration of $50 \%$ in the presence of $10 \%$ FCS. (The concentration of CM is defined as the percentage of the final volume that is concentrated $\mathrm{CM}$.) To determine the serum dependence of the growth factor activity in fibroblast $\mathrm{CM}$, the concentrated $\mathrm{CM}$ was tested at a concentration of $50 \%$ in the presence of $0,1,3,5,10$, and $20 \%$ FCS.
Characterization of growth stimulatory activity. To characterize the mitogenic activity in the human lung fibroblast-CM, various biophysical properties of the stimulatory activity in the concentrated fibroblast$\mathrm{CM}$ were determined. Heat stability was determined by heating the fibroblast-CM to $65^{\circ} \mathrm{C}$ for $30 \mathrm{~min}$ or to boiling for $10 \mathrm{~min}$. To assess the effect of enzymatic protease treatment, the fibroblast-CM was treated with trypsin or pepsin. The $\mathrm{CM}$ was incubated with $1 \mathrm{mg} / \mathrm{ml}$ trypsin at $37^{\circ} \mathrm{C}$ for $2 \mathrm{~h}$ and the trypsin was inactivated with $2 \mathrm{mg} / \mathrm{ml}$ soybean trypsin inhibitor. As a control, the CM was incubated with $2 \mathrm{mg} / \mathrm{ml}$ soybean trypsin inhibitor at $37^{\circ} \mathrm{C}$ for $2 \mathrm{~h}$. For the pepsin enzymatic digestion, the $\mathrm{pH}$ of the $\mathrm{CM}$ was adjusted to 2.5 with $1 \mathrm{~N} \mathrm{HCl}$, and the $\mathrm{CM}$ was incubated with $0.2 \mathrm{mg} / \mathrm{ml}$ pepsin at $37^{\circ} \mathrm{C}$ for $2 \mathrm{~h}$ and the $\mathrm{pH}$ was then readjusted to 7.4 with $1 \mathrm{~N} \mathrm{NaOH}$. Reduction by DTT was determined by maintaining the CM in $2 \mathrm{mM}$ DTT at $37^{\circ} \mathrm{C}$ for $2 \mathrm{~h}$. Sensitivity to acid was determined by adjusting the $\mathrm{pH}$ of the fibroblast $\mathrm{CM}$ to 2.5 with $1 \mathrm{~N} \mathrm{HCl}$, incubating the $\mathrm{CM}$ at $37^{\circ} \mathrm{C}$ for $2 \mathrm{~h}$, and readjusting the $\mathrm{pH}$ to 7.4 with $1 \mathrm{M} \mathrm{NaOH}$. After each treatment, the CM was dialyzed against DME, diluted twofold with DME, and incubated with alveolar type II cells in the presence of $\left[{ }^{3} \mathrm{H}\right]$ thymidine and $10 \%$ FCS from day 1 to 3 in culture. To determine if fibroblast-CM activity was additive with known growth factors for alveolar type II cells, saturating concentrations of insulin $(10 \mu \mathrm{g} / \mathrm{ml})$, EGF $(20 \mathrm{ng} /$ $\mathrm{ml})$, and aFGF $(200 \mathrm{ng} / \mathrm{ml})$ alone or in combination were tested in the presence or absence of $50 \%$ concentrated fibroblast-CM.

Identification of $K G F$ and $H G F / S F$ in the $C M$. The stimulatory activity in the fibroblast-CM supernatant was partially purified by heparin-Sepharose affinity chromatography. The fibroblast-CM was harvested after $48 \mathrm{~h}$ of conditioning, filtered through a $0.45-\mu \mathrm{m}$ filter, and frozen at $-20^{\circ} \mathrm{C}$ before use. Approximately $150-200 \mathrm{ml}$ of the fibroblast-CM was loaded onto a heparin-Sepharose column (Pharmacia Inc., Piscataway, $\mathrm{NJ}$ ) with a bed volume of $4 \mathrm{ml}$. The column was washed with $0.2 \mathrm{M} \mathrm{NaCl}$ in $20 \mathrm{mM}$ Tris ( $\mathrm{pH} \mathrm{7.5)} \mathrm{until} \mathrm{the} \mathrm{A}_{280}$ was 0 and eluted at a flow rate of $20 \mathrm{ml} / \mathrm{h}$ with a step gradient of increasing $\mathrm{NaCl}$ concentration in $20 \mathrm{mM}$ Tris ( $\mathrm{pH} 7.5$ ). 6-ml fractions were collected and dialyzed against DME, diluted 2-fold with DME, and incubated with alveolar type II cells in the presence of $10 \%$ FCS in the DNA synthesis assay.

To determine if the stimulatory activity eluting from the heparinSepharose column was due to known heparin-binding growth factors, active fractions were incubated with inhibitory antibodies to KGF or hepatocyte growth factor/scatter factor (HGF/SF) in the DNA synthesis assay. The anti-KGF antibody was a murine monoclonal antibody that, at a final concentration of $1 \mu \mathrm{g} / \mathrm{ml}$, inhibited $\geq 85 \%$ of the activity of a near maximal dose and $\geq 98 \%$ of half-maximal recombinant (r)KGF-induced stimulation of BALB/MK keratinocytes (J. S. Rubin, manuscript in preparation). The anti-HGF/SF antibody was the purified IgG fraction of serum from rabbits immunized with purified HGF/SF and inhibited $\geq 90 \%$ of the activity of half-maximal rHGF/ SF-induced stimulation of B5/ 589 human mammary epithelial cells at a dilution of 1:250 $(\sim 8 \mu \mathrm{g} / \mathrm{ml})(20)$. The anti-KGF antibody was used at a final concentration of $5.0 \mu \mathrm{g} / \mathrm{ml}$ and the anti-HGF/SF antisera was tested at a dilution of $1: 200$ in the $\left[{ }^{3} \mathrm{H}\right]$ thymidine incorporation assay with the fractions eluting from heparin-Sepharose in 0.6 and $1.0 \mathrm{M} \mathrm{NaCl}$ as well as crude $\mathrm{CM}$ (see Fig. 6). All samples were tested in the presence of $10 \%$ FCS. Bacterially expressed human rKGF and baculovirus-expressed rHGF/SF (J. S. Rubin, unpublished data) were diluted with DME alone or DME containing 10\% FCS and tested at various concentrations in the $\left[{ }^{3} \mathrm{H}\right]$ thymidine incorporation assay (see Fig. 8).

Total cellular RNA was isolated by lysis of human lung fibroblasts in guanidine isothiocyanate and centrifugation through a $\mathrm{CsCl}$ cushion (21). RNA was fractionated on $1 \%$ agarose gels containing formaldehyde and transferred to nylon membranes. The KGF probe was a 712 bp fragment corresponding to nucleotides 17-729 (22) and the HGF/ SF probe was a $2.2-\mathrm{kb}$ fragment corresponding to nucleotides -24 to +2187 (23). Probes were labeled with [ $\left.{ }^{32} \mathrm{P}\right] \mathrm{dCTP}$ using nick translation. For HGF/SF, the blots were hybridized overnight at $42^{\circ} \mathrm{C}$ in $50 \%$ formamide, $5 \times$ SSC, $10 \mathrm{mM}$ sodium phosphate, $\mathrm{pH} 6.6,0.5 \%$ SDS 
containing $50 \mu \mathrm{g} / \mathrm{ml}$ denatured salmon sperm DNA. They were then washed with $0.2 \times$ SSC, $0.1 \%$ SDS for 30 min once at room temperature and twice at $60^{\circ} \mathrm{C}$. For KGF, the blots were hybridized overnight at $42^{\circ} \mathrm{C}$ in $50 \%$ formamide, $5 \times \mathrm{SSC} / 25 \mathrm{mM}$ sodium phosphate, $\mathrm{pH} 6.6$, $2.5 \times$ Denhardt's solution containing $50 \mu \mathrm{g} / \mathrm{ml}$ denatured salmon sperm DNA and then washed with $0.2 \times$ SSC, $0.1 \%$ SDS for $30 \mathrm{~min}$ once at room temperature and twice at $60^{\circ} \mathrm{C}$.

Approximately $100 \mathrm{ng}$ of heparin-Sepharose-purified KGF from the culture supernatant of M426 fibroblasts (24) was resolved by $12.5 \%$ SDS-PAGE (25) alongside a concentrate of the $0.6 \mathrm{M} \mathrm{NaCl}$ heparinSepharose fraction obtained from $50 \mathrm{ml}$ of adult lung fibroblast-CM. Proteins were transferred to Immobilon (Millipore Corp., Bedford, MA) according to the method of Towbin et al. (26). The Immobilon

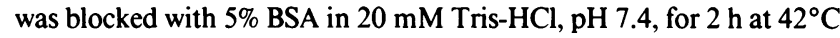
and blotted with $0.1 \mu \mathrm{g} / \mathrm{ml}$ affinity-purified rabbit polyclonal antiserum raised against a synthetic peptide corresponding to the carboxyterminal 14 amino acids of the KGF sequence (22). After a 1-h incubation at room temperature, the blot was washed six times with PBS, $0.05 \%$ Tween, $0.02 \%$ azide, incubated with [ ${ }^{125} \mathrm{I}$ ] protein A for $30 \mathrm{~min}$ at room temperature, washed six times with PBS, Tween, azide, and exposed to $\mathrm{x}$-ray film at $-70^{\circ} \mathrm{C}$. To detect $\mathrm{HGF} / \mathrm{SF}$ by immunoblotting, $\sim 40 \mathrm{ml}$ of fibroblast-CM was incubated with $200 \mu \mathrm{l}$ of a $50 \%$ heparin-Sepharose slurry in $20 \mathrm{mM}$ Tris, $0.3 \mathrm{M} \mathrm{NaCl}$, pH 7.4 for 4-5 h at $4^{\circ} \mathrm{C}$. The resin was precipitated by centrifugation, washed with equilibration buffer, and eluted with $60 \mu \mathrm{l}$ of Laemmli buffer, which was loaded directly onto a $12.5 \%$ polyacrylamide gel. The purified IgG fraction of anti-HGF/SF rabbit polyclonal serum $(\sim 8 \mu \mathrm{g} / \mathrm{ml})$ was used to detect $\mathrm{HGF} / \mathrm{SF}$ using the same protocol as for KGF.

\section{Results}

Time-dependent accumulation and serum dependence of fibroblast-CM stimulatory activity. Initial studies were performed with fibroblasts isolated from embryonic and adult rat lungs by mechanical disruption and explant culture. Medium conditioned by these fibroblasts stimulated alveolar type II cell DNA synthesis in the $\left[{ }^{3} \mathrm{H}\right]$ thymidine incorporation assay but this activity was dependent upon the fibroblast isolation and the passage number. Whereas there was no apparent difference in stimulatory activity between medium conditioned by fetal and adult fibroblasts, CM derived from fibroblasts maintained in culture for $>3 \mathrm{wk}$ had decreased stimulatory activity compared with freshly isolated fibroblasts (data not shown). In contrast, medium conditioned by the human lung fibroblast cell line AG02262 maintained constant stimulatory activity for several months while being maintained in DME and $10 \%$ FCS and passaged every 5-7 d. CM was obtained throughout this period. In addition, fibroblasts were maintained in roller bottles and cycled (periods of DME supplemented with 10\% FCS alternating with DME alone). Cells were maintained and media conditioned under these conditions for $\sim 2 \mathrm{mo}$.

The human lung fibroblast-CM stimulatory activity accumulated in a time-dependent manner (Fig. 1). Activity increased rapidly over the first $12 \mathrm{~h}$ and was maximal after $48 \mathrm{~h}$. To determine if the conditioning and processing protocol altered the DME and produced stimulatory activity, DME was incubated for $48 \mathrm{~h}$ in the absence of fibroblasts and processed in the same manner as the fibroblast-CM. This medium did not stimulate DNA synthesis in alveolar type II cells (data not shown).

The fibroblast-CM stimulatory activity for alveolar type II cells demonstrated an absolute requirement for serum (Fig. 2). At FCS concentrations $<3 \%, 50 \%$ concentrated $\mathrm{CM}$ did not stimulate an increase in DNA synthesis (data not shown).

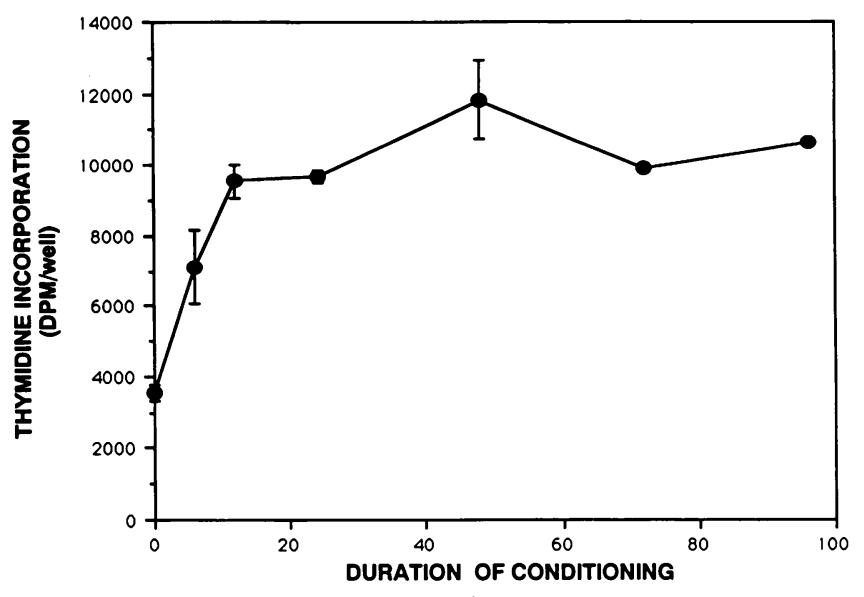

(h)

Figure 1. Time-dependent accumulation of human lung fibroblast$\mathrm{CM}$ growth factor activity. Human lung fibroblasts were grown to confluence in DME supplemented with $10 \%$ FCS. The cells were washed with DME and then incubated with unsupplemented medium. The CM was concentrated fivefold by lyophilization. Alveolar type II cells were isolated from adult male rats by elastase dissociation and purification on discontinuous metrizamide gradients. The type II cells were incubated with $\left[{ }^{3} \mathrm{H}\right]$ thymidine and $50 \%$ concentrated $\mathrm{CM}$ supplemented with $10 \%$ serum from day 1 to 3 in culture. Values are the mean \pm SEM of four experiments.

Half-maximal stimulatory activity occurred at 5\% FCS and the stimulatory activity was maximal at $10 \% \mathrm{FCS}$. In the presence of $10 \%$ FCS, the stimulatory activity of fibroblast-CM was concentration dependent (Fig. 2). Half-maximal activity occurred at $10 \%$ concentrated $\mathrm{CM}$ and maximal activity was produced by $50 \%$ concentrated $\mathrm{CM}$.

To demonstrate that the thymidine incorporation was occurring in type II cells and to evaluate cell proliferation, alveolar type II cell-labeling indexes and changes in cell number were measured. When type II cells were incubated with $10 \%$ FCS from day 1 to 3 of culture, the cell number increased from $18.1 \pm 1.4 \times 10^{4}$ at day 1 to $25.7 \pm 2.2 \times 10^{4}$ at day 3

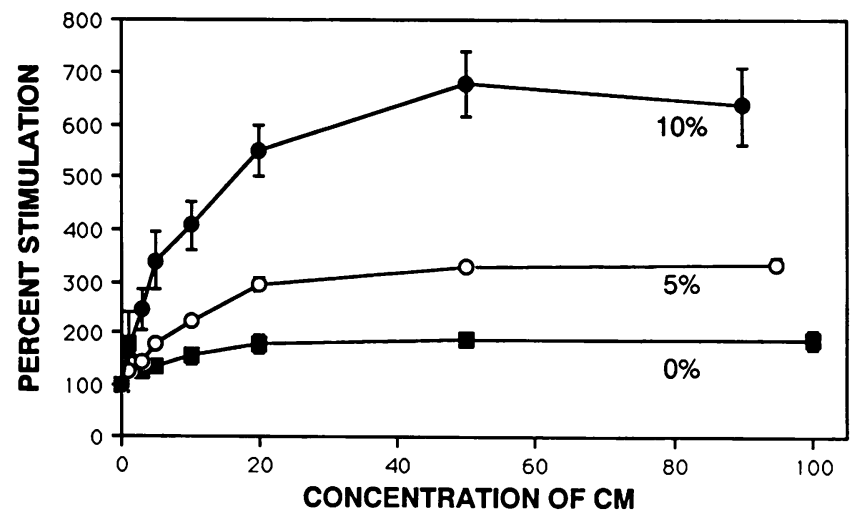

Figure 2. Growth factor activity in fibroblast-CM is concentration and serum dependent. The cells were incubated with $\left[{ }^{3} \mathrm{H}\right]$ thymidine and varying concentrations of fivefold concentrated $\mathrm{CM}$ and serum (filled circles, 10\%; open circles, 5\%; filled squares, 0\%) from day 1 to 3 in culture. $\left[{ }^{3} \mathrm{H}\right]$ Thymidine incorporation is expressed as percent stimulation; $100 \%$ is the level of thymidine incorporation in the absence of $\mathrm{CM}$. Values are the mean $\pm \mathrm{SEM}$ of four experiments. 
(mean \pm SEM, $n=4$ ). In the presence of $10 \%$ FCS supplemented with $10 \mathrm{ng} / \mathrm{ml} \mathrm{rHGF} / \mathrm{SF}, 10 \mathrm{ng} / \mathrm{ml} \mathrm{rKGF}$, or both factors together, the cell number increased to $31.9 \pm 2.5$, $34.7 \pm 3.0$, and $46.8 \pm 5.8 \times 10^{4}$ at day $3(P=0.05, P<0.02, P$ $<0.01$, respectively, compared with cells cultured in $10 \%$ FCS alone). rHGF/SF and rKGF increased the alveolar type II cell-labeling index (Table I). Thus, rKGF and rHGF/SF induced not only alveolar type II cell DNA synthesis but also stimulated cellular division and an increase in type II cell number.

Partial characterization of the fibroblast-CM stimulatory activity. The fibroblast-CM was subjected to the treatments outlined in Fig. 3. These studies demonstrated that the stimulatory activity was trypsin and pepsin sensitive, heat labile, and partially diminished by acid or reduction with DTT. The fibroblast-derived stimulatory activity was additive with all growth factors for alveolar type II cells tested individually or in combination (Fig. 4). EGF, insulin, and aFGF were tested at maximal stimulatory concentrations, suggesting that the stimulatory activity in the fibroblast-CM was different from these previously identified growth factors for alveolar type II cells.

Identification of $K G F$ and $H G F / S F$. The stimulatory activity of the fibroblast-CM was partially purified by heparin-Sepharose affinity chromatography. Crude $\mathrm{CM}$ was applied to a heparin-Sepharose column and eluted with a step gradient of increasing salt concentration. Stimulatory activity eluted from heparin-Sepharose in 0.6 and $1.0 \mathrm{M} \mathrm{NaCl}$ (Fig. 5). Because the flowthrough from the heparin-Sepharose column did not stimulate type II cell DNA synthesis (data not shown), the stimulatory activity in the fibroblast-CM was due to at least two distinct heparin-binding fractions.

To determine if the stimulatory activity of the fibroblast$\mathrm{CM}$ was attributable to $\mathrm{KGF}$ and $\mathrm{HGF} / \mathrm{SF}$, two heparin-binding growth factors that elute from heparin-Sepharose in 0.6 and $0.8-1.0 \mathrm{M} \mathrm{NaCl}$, respectively, the crude $\mathrm{CM}$, and the fractions eluting from heparin-Sepharose in 0.6 and $1.0 \mathrm{M} \mathrm{NaCl}$ were incubated with neutralizing antibodies to KGF and HGF/SF in the alveolar type II cell DNA synthesis assay (Fig. 6). The

Table I. rHGF/SF and rKGF Increased the Alveolar Type II Cell-labeling Index

\begin{tabular}{|c|c|c|c|c|c|}
\hline \multirow[b]{3}{*}{ Condition } & \multirow[b]{3}{*}{ Purity } & \multicolumn{4}{|c|}{ Alveolar type II cells } \\
\hline & & \multicolumn{2}{|c|}{ Mononuclear } & \multicolumn{2}{|c|}{ Binuclear } \\
\hline & & Labeled & Unlabeled & Labeled & Unlabeled \\
\hline & & \multicolumn{4}{|c|}{$\%$} \\
\hline FCS & $90.9 \pm 0.9$ & $2.9 \pm 0.8$ & $96.2 \pm 0.7$ & $0.2 \pm 0.2$ & $0.8 \pm 0.3$ \\
\hline $\mathrm{rHGF} / \mathrm{SF}$ & $89.7 \pm 0.7$ & $5.3 \pm 1.4$ & $92.7 \pm 1.5$ & $1.2 \pm 0.3$ & $0.9 \pm 0.2$ \\
\hline rKGF & $90.4 \pm 0.8$ & $6.1 \pm 1.5$ & $91.7 \pm 1.2$ & $1.4 \pm 0.2$ & $1.2 \pm 0.3$ \\
\hline $\begin{array}{c}\mathrm{rHGF} / \mathrm{SF}+ \\
\mathrm{rKGF}\end{array}$ & $88.0 \pm 0.9$ & $15.1 \pm 3.3$ & $79.5 \pm 4.0$ & $4.7 \pm 1.3$ & $0.6 \pm 0.3$ \\
\hline
\end{tabular}

Alveolar type II cells were incubated with $10 \mathrm{ng} / \mathrm{ml} \mathrm{rHGF/SF,} 10 \mathrm{ng} /$ $\mathrm{ml} \mathrm{rKGF}$, or both factors in the presence of $10 \%$ FCS from day 1 to 3 of culture. Autoradiography was performed and type II cells were identified by their characteristic inclusions by staining with osmium tetroxide and tannic acid. The alveolar type II cell-labeling index was calculated as previously described (11). Data are expressed as mean \pm SEM, $n=4$.

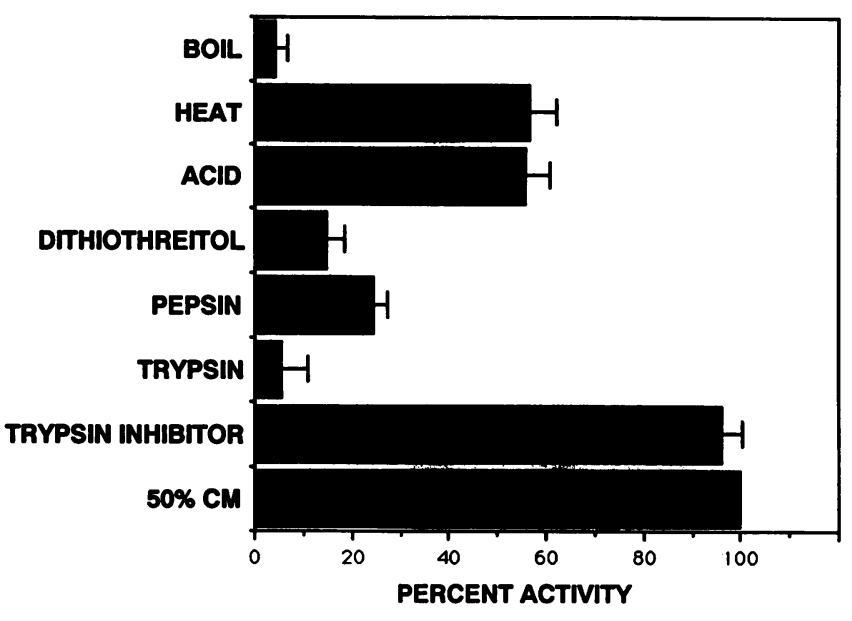

Figure 3. Partial characterization of the growth factor activity in fibroblast-CM. CM and alveolar type II cells were prepared as described in Fig. 1. The $\mathrm{CM}$ was subjected to the following treatments: $B O I L$, $\mathrm{CM}$ was boiled for $10 \mathrm{~min} ; H E A T, \mathrm{CM}$ was heated to $65^{\circ} \mathrm{C}$ for 30 min; $A C I D, \mathrm{pH}$ of $\mathrm{CM}$ was adjusted to 2.5 with $1 \mathrm{~N} \mathrm{HCl}$ and the $\mathrm{CM}$ was incubated at $37^{\circ} \mathrm{C}$ for $2 \mathrm{~h}$ and then the $\mathrm{pH}$ was readjusted to 7.4 with $1 \mathrm{M} \mathrm{NaOH}$; DITHIOTHREITOL, CM was incubated with $2 \mathrm{mM}$ dithiothreitol at $37^{\circ} \mathrm{C}$ for $2 \mathrm{~h}$; PEPSIN, pH of CM was adjusted to 2.5 with $1 \mathrm{~N} \mathrm{HCl}$ and the $\mathrm{CM}$ was incubated with 0.2 $\mathrm{mg} / \mathrm{ml}$ pepsin at $37^{\circ} \mathrm{C}$ for $2 \mathrm{~h}$ and the $\mathrm{pH}$ was readjusted to 7.4 with $1 \mathrm{M} \mathrm{NaOH}$; TRYPSIN, CM was incubated with $1 \mathrm{mg} / \mathrm{ml}$ trypsin at $37^{\circ} \mathrm{C}$ for $2 \mathrm{~h}$ and the trypsin was inactivated with $2 \mathrm{mg} / \mathrm{ml}$ soybean trypsin inhibitor; TRYPSIN INHIBITOR, CM was incubated with $2 \mathrm{mg} / \mathrm{ml}$ soybean trypsin inhibitor at $37^{\circ} \mathrm{C}$ for $2 \mathrm{~h} .50 \% \mathrm{CM}$, untreated concentrated $\mathrm{CM}$. After each treatment, the $\mathrm{CM}$ was dialyzed against DME, diluted twofold with DME, and incubated with type II cells in the presence of $\left[{ }^{3} \mathrm{H}\right]$ thymidine and $10 \%$ FCS from day 1 to 3 in culture. Percent activity was calculated from the thymidine incorporation (decay per minute per well) by this formula: $100 \times[$ (test condition $-10 \% \mathrm{FCS}$ alone $) /(50 \% \mathrm{CM}-10 \% \mathrm{FCS}$ alone $)]$. Values are the mean $\pm \mathrm{SEM}$ of four experiments.

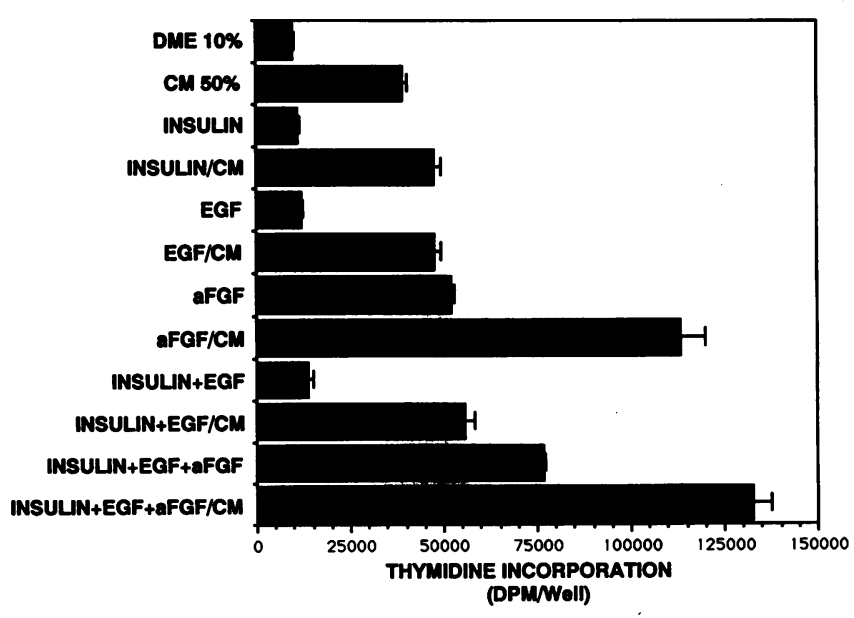

Figure 4. Activity of fibroblast-CM is additive with known growth factors for alveolar type II cells. CM and type II cells were prepared as in Fig. 1. Type II cells were incubated with $\left[{ }^{3} \mathrm{H}\right]$ thymidine, $10 \%$ FCS, and saturating doses of growth factors known to stimulate type II cell DNA synthesis: insulin $(10 \mu \mathrm{g} / \mathrm{ml}) ; E G F$, epidermal growth factor $(20 \mathrm{ng} / \mathrm{ml}) ; a F G F$, acidic fibroblast growth factor $(200 \mathrm{ng} /$ $\mathrm{ml}$ ), in the presence or absence of $50 \%$ concentrated $\mathrm{CM}$ from day 1 to 3 of culture. DME $10 \%$ is DME supplemented with $10 \%$ serum. Values are the mean \pm SEM of four experiments. 


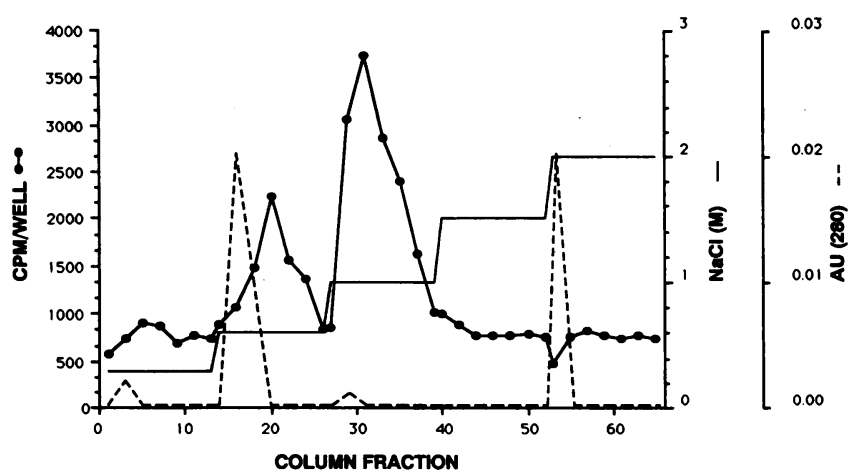

Figure 5. Heparin-Sepharose chromatography of fibroblast-CM demonstrates stimulatory activity eluting in 0.6 and $1.0 \mathrm{M} \mathrm{NaCl} .120 \mathrm{ml}$ of fibroblast-CM was loaded onto a heparin-Sepharose column (4.0$\mathrm{ml}$ bed volume). The column was washed with $0.2 \mathrm{M} \mathrm{NaCl}$ in 20 mM Tris, $\mathrm{pH} 7.5$, until the $\mathrm{A}_{280}$ was 0 and eluted with a step gradient of increasing $\mathrm{NaCl}$ concentration in $20 \mathrm{mM}$ Tris, $\mathrm{pH}$ 7.5. 6-ml fractions were eluted at a flow rate of $20 \mathrm{ml} / \mathrm{h}$. The fractions were dialyzed against DME, diluted twofold with DME, and incubated with type II cells in the presence of $10 \%$ FCS $\left[{ }^{3} \mathrm{H}\right]$ thymidine from day 1 to 3 of culture. A representative experiment of many similar elution profiles is shown.

anti-KGF antibody inhibited $80 \pm 11 \%$ of the activity eluting in $0.6 \mathrm{M} \mathrm{NaCl}$ and the anti-HGF/SF antisera blocked $84 \pm 5 \%$ of the activity eluting in $1.0 \mathrm{M} \mathrm{NaCl}(n=3)$. Neither antibody

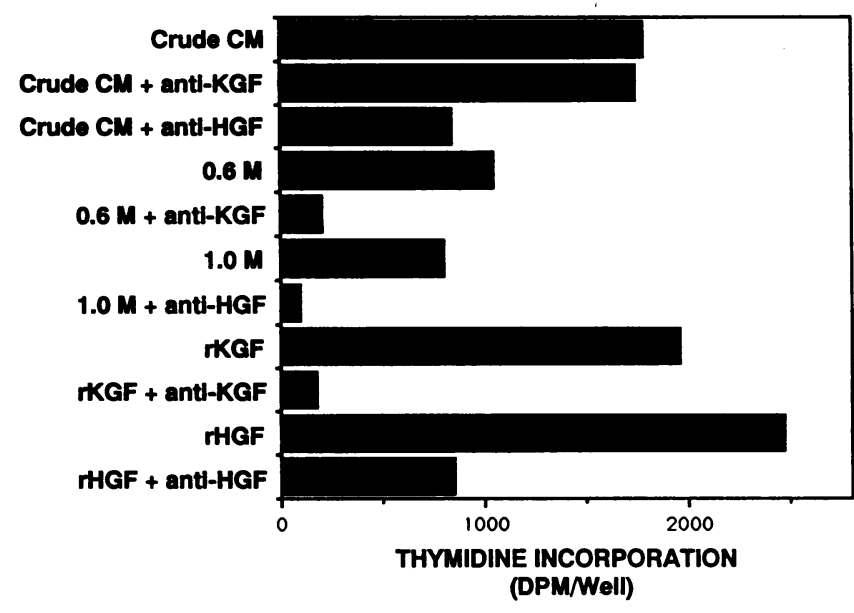

Figure 6. Stimulatory activity eluting from heparin-Sepharose in $\mathbf{0 . 6}$ and $1.0 \mathrm{M} \mathrm{NaCl}$ is inhibited by neutralizing antibodies to $\mathrm{KGF}$ and HGF/SF, respectively. Heparin-Sepharose chromatography and sample preparation were performed as described in Fig. $5.15 \mathrm{~min}$ before adding the samples to the alveolar type II cells, neutralizing antibodies were added to the indicated samples. The anti-KGF murine monoclonal antibody was tested at a final concentration of 5.0 $\mu \mathrm{g} / \mathrm{ml}$ and the rabbit anti-HGF/SF sera was tested at a dilution of $1: 200$. Crude $C M$ is unprocessed fibroblast-CM tested at $1: 10$ dilution; $0.6 \mathrm{M}$ is the fraction eluting from heparin-Sepharose in $0.6 \mathrm{M}$ $\mathrm{NaCl}$ tested at $1: 10$ dilution; $1.0 \mathrm{M}$ is the fraction eluting from heparin-Sepharose in $1.0 \mathrm{M} \mathrm{NaCl}$ tested at 1:5 dilution; rKGF was tested at $1 \mathrm{ng} / \mathrm{ml} ; \mathrm{rHGF} / \mathrm{SF}$ was tested at $1 \mathrm{ng} / \mathrm{ml}$. All samples were tested in the presence of $10 \%$ FCS. Thymidine incorporation is expressed as: measured thymidine incorporation (cells incubated with the test condition) - basal thymidine incorporation (cells incubated with DME supplemented with $10 \%$ FCS only), 1,980 dpm per well. A representative experiment is shown; these data were reproduced in two additional independent experiments. inhibited basal thymidine incorporation by type II cells incubated in the presence of $10 \%$ serum. On the basis of the degree of inhibition of the crude CM activity by the anti-KGF and anti-HGF/SF antibodies and the absolute level of thymidine incorporation induced by the fractions eluting in 0.6 and $1.0 \mathrm{M}$ $\mathrm{NaCl}, \mathrm{HGF} / \mathrm{SF}$ appears to be the dominant stimulant of alveolar type II cell DNA synthesis in the fibroblast-CM.

$\mathrm{KGF}$ was demonstrated in the $0.6 \mathrm{M} \mathrm{NaCl}$ heparin-Sepharose fraction and $\mathrm{HGF} / \mathrm{SF}$ was detected in the crude $\mathrm{CM}$ by immunoblotting (Fig. 7, $A$ and $B$, respectively). The human lung fibroblasts expressed transcripts for both KGF and HGF/ SF (Fig. $7 C$ ). Both rKGF and rHGF/SF induced type II cell

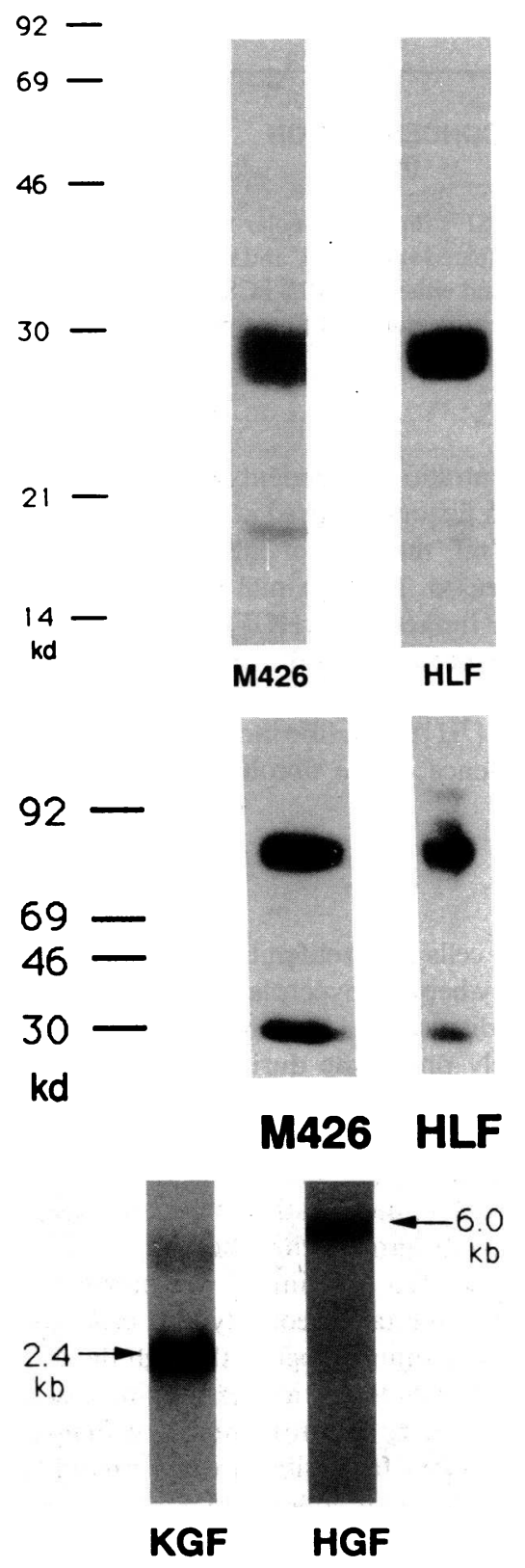

Figure 7. (A) Immunoblot demonstrating $\mathrm{KGF}$ in the $0.6 \mathrm{M} \mathrm{NaCl}$ fraction eluting from heparin-Sepharose. CM was processed and chromatography was performed as in Fig. 5. The $0.6 \mathrm{M} \mathrm{NaCl}$ heparin-Sepharose fraction was concentrated, resolved by $12.5 \%$ SDSPAGE, transferred to Immobilon, and incubated with rabbit antisera to KGF. The M426 sample was heparin-Sepharose-purified KGF isolated from M426-CM, the original source of KGF (24). In addition to the 26-28-kD KGF band, an $\sim 18-\mathrm{kD}$ proteolytic fragment was observed in both M426 and adult human lung fibroblast ( $H L F)$ CM. (B) Immunoblot demonstrating HGF/SF in the crude fibroblast CM.

Heparin-Sepharose was incubated with $\mathrm{CM}$ and eluted with Laemmli buffer, which was loaded directly onto a $12.5 \%$ polyacrylamide gel. HGF/SF was detected as described in Methods. M426 and HLF CM were processed in parallel. The $\sim 75-\mathrm{kD}$ band corresponded to HGF/SF, whereas the $\sim 30-\mathrm{kD}$ band represented the product of an alterna-

tively spliced, truncated form of HGF/SF (74) (C) Northern blot analysis of KGF and HGF/SF mRNA expression in HLF. Total RNA $(10 \mu \mathrm{g})$ from HLF was separated by electrophoresis on $1 \%$ agarose containing formaldehyde and hybridized with either KGF or HGF/SF probes. The sizes in kilobases of the major transcripts were determined by comparison with RNA standards. 


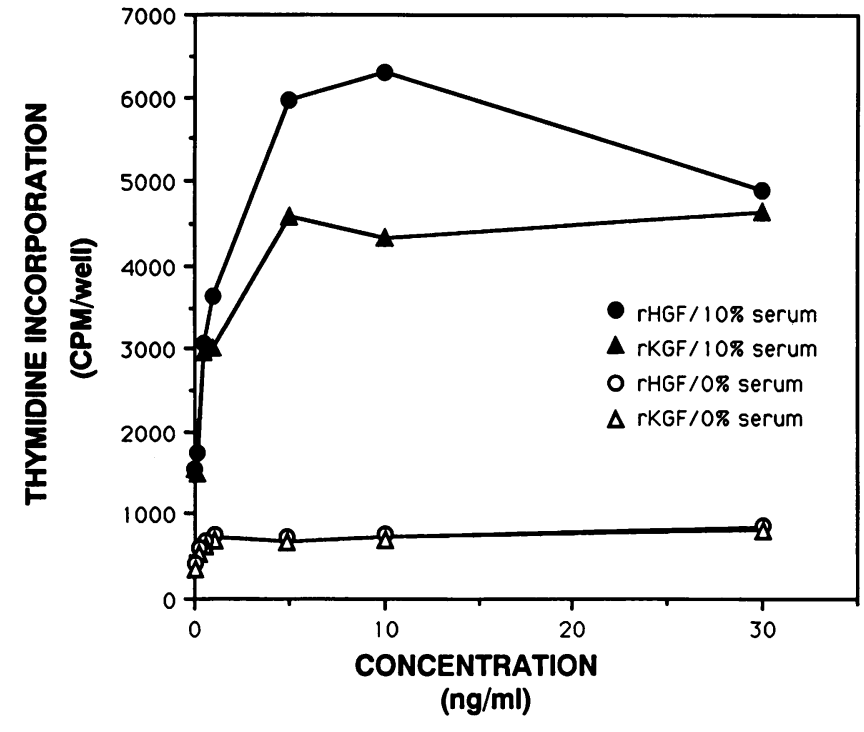

Figure 8. rKGF and rHGF/SF stimulate alveolar type II DNA synthesis. Type II cells were incubated with rKGF and rHGF/SF in the presence of $\left[{ }^{3} \mathrm{H}\right]$ thymidine and either 0 or $10 \%$ FCS from day 1 to 3 in culture. An experiment representative of four similar studies is shown.

DNA synthesis in a concentration-dependent manner (Fig. 8). Maximal activity for both factors occurred at $5-10 \mathrm{ng} / \mathrm{ml}$. At concentrations $>10 \mathrm{ng} / \mathrm{ml}$, the level of DNA synthesis induced by $\mathrm{rHGF} / \mathrm{SF}$ decreased. The maximal absolute level of thymidine incorporation induced by $\mathrm{rHGF} / \mathrm{SF}$ was $\sim 30$ $35 \%$ greater than that induced by rKGF. In addition, when tested in the absence of serum, both rKGF and rHGF/SF produced $<50 \%$ increases in $\left[{ }^{3} \mathrm{H}\right]$ thymidine incorporation, similar to the serum dependence of the fibroblast-CM (Figs. 2 and 8 ).

\section{Discussion}

Although alveolar type II cells are proliferatively quiescent in normal adult animals, they become hyperplastic and hypertrophic in many pulmonary diseases and lung injury models (2732). Type II cells actively proliferate during neonatal lung growth and, when they are isolated, these cells multiply in primary culture (33-36). In contrast, normal adult type II cells do not multiply in vitro in the absence of mitogens (6) and, in the presence of growth factors, their proliferation is limited $(3,6)$. Few studies have examined the growth characteristics of adult alveolar type II cells isolated after lung injury. We previously demonstrated that hypertrophic rat alveolar type II cells isolated after silica-induced lung injury progress through the cell cycle, are committed to DNA synthesis, and exhibit increased levels of DNA synthesis in primary culture compared with normotrophic type II cells isolated from silica-treated rats (11, 37). Although repair of the alveolar epithelium after lung injury presumably is important for the restoration of normal alveolar architecture and physiological function, the factors controlling the regulation of alveolar type II cell hyperplasia and hypertrophy are not known. Several investigators have demonstrated that medium conditioned by lung macrophages or fibroblasts can stimulate DNA synthesis in alveolar epithelial cells $(7,9,16,17,38)$; however, no specific growth factor(s) have been identified from either macrophage or fibroblast-CM. In this report we demonstrate that human adult lung fibroblasts produce $\mathrm{KGF}$ and $\mathrm{HGF} / \mathrm{SF}$ and that these factors stimulate DNA synthesis and proliferation of rat alveolar type II cells in primary culture.

Several properties of the adult human lung fibroblast-CM suggest that most if not all of the activity stimulating alveolar type II cell DNA synthesis is due to KGF and HGF/SF. The activity was heat and partially acid labile and sensitive to protease degradation. The additive effect of the fibroblast-CM with saturating concentrations of aFGF, EGF, and insulin indicated that the CM contained one or more agents that would act through receptors other than the ones recognized by these factors. The CM activity was separated into two peaks of activity by heparin-Sepharose affinity chromatography. The first peak eluted from heparin-Sepharose in $0.6 \mathrm{M} \mathrm{NaCl}$, suggesting that the heparin affinity of this activity was similar to KGF. Further, this activity was inhibited by a neutralizing murine monoclonal antibody that is specific for KGF. By immunoblot analysis, the $0.6 \mathrm{M} \mathrm{NaCl}$ eluent contained an immunoreactive protein with a molecular mass of $26-28 \mathrm{kD}$, indistinguishable from KGF. The second peak of activity eluted from heparinSepharose with a $\mathrm{NaCl}$ concentration corresponding to that required for HGF/SF. This activity was completely blocked by a rabbit antiserum that specifically neutralizes the mitogenic effect of HGF/SF. Western blot analysis detected an $\sim 75-\mathrm{kD}$ protein in crude CM under nonreducing conditions that corresponds to HGF/SF. Also, the adult human lung fibroblasts expressed transcripts for both KGF and HGF/SF. Finally, human rKGF and rHGF/SF stimulated alveolar type II cell DNA synthesis in vitro in a manner similar to that seen with the CM. Thus, the stimulatory activity for alveolar type II cells in fibroblast-CM appears due largely, if not exclusively, to the heparinbinding growth factors KGF and HGF/SF. On the basis of the degree of inhibition of the fibroblast-CM stimulatory activity by the anti-KGF and anti-HGF/SF antibodies and the difference in mitogenic potency of the 0.6 and $1.0 \mathrm{M} \mathrm{NaCl}$ heparinSepharose fractions as well as rKGF and rHGF/SF, HGF/SF appears to be the dominant heparin-binding growth factor for alveolar type II cells in fibroblast-CM.

KGF is a recently described epithelial cell-specific heparinbinding growth factor that was originally isolated from the $\mathrm{CM}$ supernatant of the human embryonic lung fibroblast cell line M426 (24). The KGF gene appears to be transcribed as two alternative mRNAs, a predominant $2.4-\mathrm{kb}$ transcript and a less abundant $5-\mathrm{kb}$ transcript. KGF mRNA is translated into a monomeric polypeptide that is both acid and heat sensitive and has an apparent molecular mass of $28 \mathrm{kD}$ according to SDS/ PAGE. KGF (FGF-7) is a member of the fibroblast growth factor family, which includes acidic and basic FGF (FGF-1 and FGF-2, respectively), Int-2 (FGF-3), HST (FGF-4), FGF-5, and FGF-6 (22, 39-41). Unlike acidic and basic FGF, the primary KGF translation product contains a hydrophobic aminoterminal peptide sequence that is not present in the mature KGF molecule, suggesting that it is a signal sequence for secretion (22). KGF mRNA is expressed in various tissues including normal adult kidney, colon, and ileum (22). In contrast to the other known members of the FGF family, KGF has a unique target cell specificity restricted to epithelial cell types $(22,24)$ whereas acidic and basic FGF also exert potent effects on fibroblasts, endothelial cells, melanocytes, and neurons (39). Analysis of the interaction of KGF with BALB/MK 
mouse epidermal keratinocytes demonstrated saturable specific high affinity binding as well as a high capacity/low affinity heparin-like binding site (42). The high affinity KGF receptors on BALB/MK keratinocytes bind aFGF equally well but bFGF with an order of magnitude lower affinity. Molecular cloning of the KGF receptor established that it is a membranespanning tyrosine kinase derived from an alternatively spliced form of the bek (FGFR-2) gene $(43,44)$. This alternatively spliced transcript has only been detected in epithelial cells and, thus, may account for the unique target cell specificity of KGF. $b e k$ is expressed in the epithelium of the bronchial tree and the alveoli in the embryonic mouse $(45,46)$.

$\mathrm{HGF} / \mathrm{SF}$ is a heparin-binding growth factor that was initially isolated from plasma $(47,48)$ and platelets $(49,50)$ and more recently purified from CM supernatant of the human embryonic lung fibroblast cell line M426 (20). HGF/SF is a disulfide-linked heterodimer consisting of a 55-60-kD alpha subunit and a $32-34-\mathrm{kD}$ beta subunit $(47,48,50)$ that are proteolytically derived from a single precursor polypeptide (23, 51). The cDNA of HGF/SF reveals no homology with known growth factors but is $\sim 38 \%$ identical to plasminogen, including the presence of four kringles and a serine protease-like domain. Northern blot analysis has demonstrated the expression of HGF/SF mRNA in various tissues, including the liver, kidney, lung, and brain (52); in stromal fibroblasts derived from adult skin, lung, gastrointestinal tract and prostate; and in embryonic lung fibroblasts (20). Immunohistochemical studies have demonstrated HGF/SF immunoreactivity in the tracheal, bronchial, and bronchiolar epithelium and in endothelial cells and macrophages within the alveolus (53). HGF/SF is mitogenic for hepatocytes, epithelial cells, melanocytes, and endothelial cells but does not stimulate fibroblast DNA synthesis $(20,54,55)$. HGF/SF is identical to scatter factor $(56,57)$, a fibroblast- and smooth muscle cell-derived factor that stimulates epithelial and endothelial cell motility and causes the dissociation of epithelial cell colonies (58-60). The hepatocyte growth factor receptor is the c-met protooncogene product ( 61 , 62 ) and met is expressed highly in mouse lung tissue $(63,64)$. In addition, HGF/SF binds specifically to plasma membranes isolated from lung tissue (64).

Neither fibroblast-CM nor rKGF or $\mathrm{rHGF} / \mathrm{SF}$ stimulated alveolar type II cell DNA synthesis in the absence of serum. In the presence of $50 \%$ concentrated $\mathrm{CM}$, half-maximal stimulatory activity occurred at 5\% FCS and maximal activity occurred at $10 \%$ FCS (Fig. 2). Similarly, aFGF does not effectively induce type II cell DNA synthesis in the absence of serum (8). Thus, serum contains components that are necessary for these heparin-binding growth factors to stimulate DNA synthesis in type II cells. Leslie et al. (8) showed that rat HDL could substitute effectively for serum in the presence of aFGF. However, the mechanism by which HDL enables aFGF to stimulate alveolar type II cell DNA synthesis is not known.

Mesenchymal cells have been shown to stimulate epithelial cell proliferation in several different systems (65-73). Fibroblast-CM stimulates mammary (65), corneal (66), tracheal $(67,68)$, and bronchial (69) epithelial cell as well as keratinocyte $(24,70)$ proliferation. In addition, clonal proliferation of mammary (71), skin (72), and bronchial (73) epithelial cells occurs when they are grown on fibroblast feeder layers. Previous studies have shown that medium conditioned by lung fibroblasts derived from hyperoxia-exposed animals (16) or fibroblasts exposed to hyperoxia in vitro (38) stimulates alveo- lar type II cell proliferation in primary culture. In addition, fetal lung fibroblast-CM stimulates DNA synthesis in fetal epithelial cells ( 17). Of all these activities only KGF and HGF/SF have been purified $(20,24)$. Shoji et al. (69) showed that medium conditioned by human fetal lung fibroblasts contained a protease-sensitive, acid-stable, nondialyzable, lipid-inextractable protein with an apparent molecular mass of $6 \mathrm{kD}$ that stimulated the proliferation of human bronchial epithelial cells. Fetal lung fibroblast-derived mitogenic activity for fetal alveolar epithelial cells was reportedly due to a heat-labile, trypsin-sensitive factor with an apparent molecular mass of 30 $\mathrm{kD}$ (17), whereas the factor produced by hyperoxia-treated lung fibroblasts that stimulated DNA synthesis in pulmonary epithelial tumor (A549) cells had an apparent molecular mass of $20-26 \mathrm{kD}(38)$. The physical properties of both these activities are consistent with KGF.

Ultrastructural studies of lung specimens obtained after lung injury provide further evidence of epithelial-mesenchymal cell interactions. Epithelial cytoplasmic protrusions extending through discontinuities in the basement membrane and forming intimate associations with stromal cells have been described in electron micrographs of lung biopsy specimens from patients with interstitial lung disease and from mice that have been exposed to butylated hydroxytoluene and hyperoxia $(14,15)$. Although these associations suggest intercellular communication between stromal and epithelial cells, their significance is not known.

In summary, we have shown that medium conditioned by human adult lung fibroblasts stimulates DNA synthesis and proliferation of rat alveolar type II cells in primary culture. This stimulatory activity is mediated by two soluble heparinbinding growth factors, KGF and HGF/SF. Human rKGF and rHGF/SF stimulate a concentration-dependent increase in alveolar type II cell DNA synthesis. Production of KGF and HGF/SF by lung fibroblasts may be important for the proliferation of alveolar type II cells after lung injury and during normal and compensatory lung growth.

\section{Acknowledgments}

We thank Xue Song Wang and Kathleen McCormick-Shannon for technical assistance, Dr. Karl Csaky for Western blot analysis of HGF/ SF, Dr. Dina Ron for engineering recombinant expression of human KGF, and Drs. Andrew Chan and Roy Jensen for recombinant expression of human HGF/SF.

This work was performed in part in the Lord and Taylor Laboratory of Lung Biochemistry in the Anna Perahia Adatto Clinical Research Center of the National Jewish Center for Immunology and Respiratory Medicine and was funded by National Institutes of Health grants HL-27353 alid HL-29891 (R. J. Mason) and an American Lung Association Research grant (R. J. Panos). R. J. Panos is a Parker B. Francis Fellow in Pulmonary Research.

\section{References}

1. Bachofen, M., and E. R. Weibel. 1974. Basic pattern of tissue repair in human lungs following unspecific injury. Chest. 65:14S-19S.

2. Campbell, E. J., and R. M. Senior. 1981. Cell injury and repair. Clin. Chest Med. 2:357-375.

3. Rannels, S. R., and D. E. Rannels. 1989. The type II pneumocyte as a model of lung cell interaction with the extracellular matrix. J. Mol. Cell. Cardiol. 21( Suppl 1):151-159.

4. Haschek, W. M., and H. Witschi. 1979. Pulmonary fibrosis-a possible mechanism. Toxicol. Appl. Pharmacol. 51:475-487. 
5. Witschi, H. P. 1976. Proliferation of type II alveolar cells: a review of common responses in toxic lung injury. Toxicology. 5:267-277.

6. Leslie, C. C., K. McCormick-Shannon, P. C. Robinson, and R. J. Mason 1985. Stimulation of DNA synthesis in cultured rat alveolar type II cells. Exp. Lung Res. 8:53-66.

7. Leslie, C. C., K. McCormick-Shannon, J. L. Cook, and R. J. Mason. 1985. Macrophages stimulate DNA synthesis in rat alveolar type II cells. Am. Rev. Respir. Dis. 132:1246-1252.

8. Leslie, C. C., K. McCormick-Shannon, and R. J. Mason. 1990. Heparinbinding growth factors stimulate DNA synthesis in rat alveolar type II cells. $\mathrm{Am}$. J. Respir. Cell Mol. Biol. 2:99-106.

9. Brandes, M. E., and J. N. Finkelstein. 1989. Stimulated rabbit alveolar macrophages secrete a growth factor for type II pneumocytes. Am. J. Respir. Cell Mol. Biol. 1:101-109.

10. Leslie, C. C., K. McCormick-Shannon, and R. J. Mason. 1989. Bronchoalveolar lavage fluid from normal rats stimulates DNA synthesis in rat alveolar type II cells. Am. Rev. Respir. Dis. 139:360-366.

11. Panos, R. J., A. Suwabe, C. C. Leslie, and R. J. Mason. 1990. Hypertrophic alveolar type II cells from silica treated rats are committed to DNA synthesis in vitro. Am. J. Respir. Cell Mol. Biol. 3:51-59.

12. Adamson, I. Y. R., and G. M. King. 1984. Sex differences in developmen of fetal rat lung. II. Quantitative morphology of epithelial-mesenchymal interactions. Lab. Invest. 50:461-468.

13. Adamson, I. Y. R., and G. M. King. 1986. Epithelial-intersitial cell interactions in fetal rat lung development accelerated by steroids. Lab. Invest. 55:145152.

14. Brody, A. R., and J. E. Craighead. 1976. Interstitial associations of cells lining air spaces in human pulmonary fibrosis. Virchows Arch. A. Pathol. Anat. Histol. 372:39-49.

15. Brody, A. R., P. Soler, F. Basset, W. M. Haschek, and H. Witschi. 1981. Epithelial-mesenchymal associations of cells in human pulmonary fibrosis and in BHT-oxygen-induced fibrosis in mice. Exp. Lung Res. 2:207-220.

16. Everett, M. M., R. J. King, M. B. Jones, and H. M. Martin. 1990. Lung fibroblasts from animals breathing $100 \%$ oxygen produce growth factors for alveolar type II cells. Am. J. Physiol. 259:L247-L254.

17. Stiles, A. D., B. T. Smith, and M. Post. 1986. Reciprocal autocrine and paracrine regulation of growth of mesenchymal and alveolar epithelial cells from fetal lung. Exp. Lung Res. 11:165-177.

18. Dobbs, L. G., E. F. Geppert, M. C. Williams, R. D. Greenleaf, and R. J. Mason. 1980. Metabolic properties and ultrastructure of alveolar type II cells isolated with elastase. Biochim. Biophys. Acta. 618:510-523.

19. Kikkawa, Y., and K. Yoneda. 1974. The type II epithelial cell of the lung. I. Method of isolation. Lab. Invest. 30:76-84.

20. Rubin, J. S., A. M.-L. Chan, D. P. Bottaro, W. H. Burgess, W. G. Taylor, A. C. Cech, D. W. Hirschfield, J. Wong, T. Miki, P. W. Finch, et al. 1991. A broad-spectrum human lung fibroblast-derived mitogen is a variant of hepatocyte growth factor. Proc. Natl. Acad. Sci. USA. 88:415-419.

21. Chirgwin, J. M., A. E. Przybyla, R. J. MacDonald, and W. J. Rutter. 1979. Isolation of biologically active ribonucleic acid from sources rich in ribonuclease Biochemistry. 18:5294-5299.

22. Finch, P. W., J. S. Rubin, T. Miki, R. Dina, and S. A. Aaronson. 1989. Human KGF is FGF-related with properties of a paracrine effector of epithelia cell growth. Science (Wash. DC). 245:752-755.

23. Miyazawa, K., H. Tsubouchi, D. Naka, K. Takahashi, M. Okigaki, N. Arakaki, H. Nakayama, S. Hirono, D. Sakiyama, K. Takahashi, et al. 1989. Molecular cloning and sequence analysis of cDNA for human hepatocyte growth factor. Biochem. Biophys. Res. Commun. 163:967-973.

24. Rubin, J. S., J. Osada, P. W. Finch, W. G. Taylor, S. Rudikoff, and S. A Aaronson. 1989. Purification and characterization of a newly identified growth factor specific for epithelial cells. Proc. Natl. Acad. Sci. USA. 86:802-806.

25. Laemmli, U. K. 1970. Cleavage of structural proteins during the assembly of the head of bacteriophage T4. Nature (Lond.). 227:680-685.

26. Towbin, H., T. Staehelin, and J. Gordon. 1979. Electrophoretic transfer of proteins from polyacrylamide gels to nitrocellulose sheets: procedure and some applications. Proc. Natl. Acad. Sci. USA. 76:4350-4354.

27. Rannels, D. E., and S. R. Rannels. 1988. Alterations in type II pneumocytes cultured after partial pneumonectomy. Am. J. Physiol. 254:C684-C690.

28. Uhal, B. D., G. D. Hess, and D. E. Rannels. 1989. Density-independen isolation of type II pneumocytes after partial pneumonectomy. Am. J. Physiol. 256:C515-C521.

29. Miller, B. E., L. A. Dethloff, and G. E. R. Hook. 1986. Silica-induced hypertrophy of type II cells in the lungs of rats. Lab. Invest. 55:153-163.

30. Miller, B. E., R. E. Chapin, K. E. Pinkerton, L. B. Gilmore, R. R. Maronpet, and G. E. R. Hook. 1987. Quantitation of silica-induced type II cell hyperplasia by using alkaline phosphatase histochemistry in glycol methacrylate embedded lung. Exp. Lung Res. 12:135-148.

31. Miller, B. E., L. A. Dethloff, B. C. Gladen, and G. E. R. Hook. 1987 Progression of type II cell hypertrophy and hyperplasia during silica-induced pulmonary inflammation. Lab. Invest. 57:546-554.

32. Chang, L.-Y., L. H. Overby, A. R. Brody, and J. D. Crapo. 1988. Progres- sive lung cell reactions and extracellular matrix production after a brief exposure to asbestos. Am. J. Pathol. 131:156-170.

33. Kauffman, S. L., P. H. Burri, and E. R. Weibel. 1974. The postnatal growth of the rat lung. Anat. Rec. 180:63-76.

34. Brody, J. S., and N. B. Kaplan. 1983. Proliferation of alveolar interstitial cells during postnatal lung growth. Am. Rev. Respir. Dis. 127:763-770.

35. Clement, A., J. Campisi, S. R. Farmer, and J. S. Brody. 1990. Constitutive expression of growth-related mRNAs in proliferating and nonproliferating lung epithelial cells in primary culture: evidence for growth-dependent translational control. Proc. Natl. Acad. Sci. USA. 87:318-322.

36. Clement, A., N. Riedel, and J. S. Brody. $1990 .{ }^{3} \mathrm{H}$-thymidine incorporation does not correlate with growth state in cultured alveolar type 2 cells. Am.J. Respir. Cell Mol. Biol. 3:159-164.

37. Panos, R. J., and R. J. Mason. 1991. Hypertrophic alveolar type II cells isolated after silica-induced lung injury are progressing through the cell cycle and maintain a commitment to DNA synthesis in primary culture. Chest. 99:27S$28 \mathrm{~S}$.

38. Tanswell, A. K. 1983. Cellular interactions in pulmonary oxygen toxicity in vitro: $\mathrm{I}$. Hyperoxic induction of fibroblast factors which alter growth and lipid metabolism of pulmonary epithelial cells. Exp. Lung Res. 5:23-36.

39. Burgess, W. H., and T. Maciag. 1989. The heparin-binding (fibroblast) growth factor family of proteins. Annu. Rev. Biochem. 58:575-606.

40. Marics, I., J. Adelaide, F. Raybaurd, M. G. Mattei, F. Coulier, J. Planche, O. deLapeyriere, and D. Birnbaum. 1989. Characterization of the HST-related FGF.6 gene, a new member of the fibroblast growth factor gene family. Oncogene. 4:335-340.

41. Baird, A., and M. Klagsbrun. 1991. The fibroblast growth factor family: an overview. Ann. N.Y. Acad. Sci. 638:xi-xii.

42. Bottaro, D. P., J. S. Rubin, R. Dina, P. W. Finch, C. Florio, and S. A Aaronson. 1990. Characterization of the receptor for keratinocyte growth factor. J. Biol. Chem. 265:12767-12770.

43. Miki, T., T. P. Fleming, D. P. Bottaro, J. S. Rubin, D. Ron, and S. A. Aaronson. 1991. Expression cDNA cloning of the KGF receptor by creation of a transforming autocrine loop. Science (Wash. DC). 251:72-75.

44. Miki, T., D. P. Bottaro, T. P. Fleming, C. L. Smith, W. H. Burgess, A. M.-L. Chan, and S. A. Aaronson. 1992. Determination of ligand-binding specificity by alternative splicing: two distinct growth factor receptors encoded by a single gene. Proc. Natl. Acad. Sci. USA. 89:246-250.

45. Orr-Urtreger, A., D. Givol, A. Yayon, Y. Yarden, and P. Lonai. 1991. Developmental expression of two murine fibroblast growth factor receptors, flg and bek. Development (Camb.). 113:1419-1434.

46. Peters, K. G., S. P. Werner, G. Chen, and L. T. Williams. 1992. Two FGF receptor genes are differentially expressed in epithelial and mesenchymal tissues during limb formation and organogenesis in the mouse. Development (Camb.). 114:233-243.

47. Gohda, E., H. Tsubouchi, H. Nakayama, S. Hirono, O. Sakiyama, K. Takahashi, H. Miyazaki, S. Hashimoto, and Y. Daikuhara. 1988. Purification and partial characterization of hepatocyte growth factor from plasma of a patient with fulminant hepatic failure. J. Clin. Invest. 81:414-419.

48. Zarnegar, R., and G. Michalopoulos. 1989. Purification and biological characterization of human hepatopoietin A, a polypeptide growth factor for hepatocytes. Cancer Res. 49:3314-3320.

49. Nakamura, T., H. Teramoto, and A. Ichihara. 1986. Purification and characterization of a growth factor from rat platelets for mature parenchymal hepatocytes in primary cultures. Proc. Natl. Acad. Sci. USA. 83:6489-6493.

50. Nakamura, T., K. Nawa, H. Ichihara, N. Kaise, and T. Nishino. 1987. Purification and subunit structure of hepatocyte growth factor from rat platelets. FEBS (Fed. Eur. Biochem. Soc.) Lett. 224:311-316.

51. Nakamura, T., T. Nishizawa, M. Hagiya, T. Seki, M. Shimonishi, A. Sugimura, K. Tashiro, and S. Shimizu. 1989. Molecular cloning and expression of human hepatocyte growth factor. Nature (Lond.). 342:440-443.

52. Tashiro, K., M. Hagiya, T. Nishizawa, T. Seki, M. Shimonishi, S. Shimuzu, and T. Nakamura. 1990. Deduced primary structure of rat hepatocyte growth factor and expression of the mRNA in rat tissues. Proc. Natl. Acad. Sci. USA. 87:3200-3204.

53. Wolf, H. K., R. Zarnegar, and G. K. Michalopoulos. 1991. Localization of hepatocyte growth factor in human and rat tissues: an immunohistochemical study. Hepatology. 14:488-494.

54. Kan, M., G. H. Zhang, R. Zarnegar, G. Michalopoulos, Y. Myoken, W. L. McKeehan, and J. I. Stevens. 1991. Hepatocyte growth factor/hepatopoietin A stimulates the growth of rat kidney proximal tubule epithelial cells (RPTE), rat nonparenchymal liver cells, human melanoma cells, mouse keratinocytes and stimulates anchorage-independent growth of SV-40 transformed RPTE. Bio chem. Biophys. Res. Commun. 174:331-337.

55. Igawa, T., S. Kanda, H. Kanetake, Y. Saitoh, A. Ichihara, Y. Tomita, and T. Nakamura. 1991. Hepatocyte growth factor is a potent mitogen for cultured rabbit renal tubular epithelial cells. Biochem. Biophys. Res. Commun. 174:831 838 .

56. Weidner, K. M., N. Arakaki, G. Hartmann, J. Vandekerckhove, S. Weingart, H. Rieder, C. Fonatsch, H. Tsubouchi, T. Hishida, Y. Daikuhara, et al 
1991. Evidence for the identity of human scatter factor and human hepatocyte growth factor. Proc. Natl. Acad. Sci. USA. 88:7001-7005.

57. Furlong, R. A., T. Takehara, W. G. Taylor, T. Nakamura, and J. S. Rubin. 1991. Comparison of biological and immunochemical properties indicates that scatter factor and hepatocyte growth factor are indistinguishable. J. Cell Sci. 100:173-177.

58. Stoker, M., and M. Perryman. 1985. An epithelial scatter factor released by embryo fibroblasts. J. Cell Sci. 77:209-223.

59. Stoker, M., E. Gherardi, M. Perryman, and J. Gray. 1987. Scatter factor is a fibroblast-derived modulator of epithelial cell mobility. Nature (Lond.). 327:239-242.

60. Stoker, M. 1989. Effect of scatter factor on motility of epithelial cells and fibroblasts. J. Cell. Physiol. 139:565-569.

61. Bottaro, D. P., J. S. Rubin, D. L. Faletto, A. M. Chan, T. E. Kmiecik, G. F. Vande Woude, and S. A. Aaronson. 1991. Identification of the hepatocyte growth factor receptor as the c-met proto-oncogene product. Science (Wash. DC). 251:802-804.

62. Naldini, L., E. Vigna, R. P. Narishmhan, G. Gaudino, R. Zarnegar, G. K. Michalopoulos, and P. M. Comoglio. 1991. Hepatocyte growth factor (HGF) stimulates the tyrosine kinase activity of the receptor encoded by the proto-oncogene c-met. Oncogene. 6:501-504.

63. Iyer, A., T. E. Kmiecik, M. Park, I. Daar, D. Blair, K. J. Dunn, P. Sutrave, J. N. Ihle, M. Bodescot, and G. F. Vande Woude. 1990. Structure, tissue-specific expression, and transforming activity of the mouse met protooncogene. Cell Growth Differ. 1:87-95.

64. Tajimo, J., O. Higuchi, K. Mizuno, and T. Nakamura. 1992. Tissue distribution of hepatocyte growth factor receptor and its exclusive down-regulation in a regenerating organ after injury. J. Biochem. 111:401-406.

65. Fentiman, I. S., J. Hurst, and J. Taylor-Papadimitriou. 1981. Nil-8 condi- tioned medium stimulates growth of human mammary epithelial cells. Breast Cancer Res. Treat. 1:375-379.

66. Chan, K. Y., and R. H. Haschke. 1983. Epithelial-stromal interactions: specific stimulation of corneal epithelial cell growth in vitro by a factor(s) from cultured stromal fibroblasts. Exp. Eye Res. 36:231-246.

67. Lee, T.-C., R. Wu, A. R. Brody, J. C. Barrett, and P. Nettesheim. 1984. Growth and differentiation of hamster tracheal epithelial cells in culture. Exp. Lung Res. 6:27-45.

68. Wu, R., G. W. Groelke, L. Y. Chang, M. E. Porter, D. Smith, and P. Nettesheim. 1982. Effects of hormones on the multiplication and differentiation of tracheal epithelial cells in culture. In Growth of Cells in Hormonally Defined Media. G. H. Sato, A. B. Pardee, and D. A. Sirbasku, editors. Vol. 9. Cold Spring Harbor Conferences of Cell Proliferation, Cold Spring Harbor, NY. 641-656.

69. Shoji, S., K. A. Rickard, H. Takizawa, R. F. Ertl, J. Linder, and S. I. Rennard. 1990. Lung fibroblasts produce growth stimulatory activity for bronchial epithelial cells. Am. Rev. Respir. Dis. 141:433-439.

70. Green, H. 1978. Cyclic AMP in relation to proliferation of the epidermal cell: a new view. Cell. 15:801-811.

71. Taylor-Papadimitrou, J., M. Shearer, and M. G. P. Stoker. 1977. Growth requirements of human mammary epithelial cells in culture. Int. J. Cancer. 20:903-908.

72. Rheinwald, J. G., and H. Green. 1975. Serial cultivation of strains of human epidermal keratinocytes: the formation of keratinizing colonies from single cells. Cell. 6:331-344.

73. Lechner, J. F., A. Haugen, H. Autrup, I. A. McClendon, B. F. Trump, and C. C. Harris. 1981. Clonal growth of epithelial cells from normal adult human bronchus. Cancer Res. 41:2294-2304.

74. Chan, A. M.-L., J. S. Rubin, D. P. Bottaro, D. W. Hirschfield, M. Chedid, and S. A. Aaronson. 1991. Identification of a competitive HGF antagonist encoded by an alternative transcript. Science (Wash. DC). 254:1382-1385. 